\title{
Influence of the forcing process on some qualitative aspects in radicchio "Rosso di Treviso tardivo" (Cichorium intybus L., group rubifolium). 1. Nitrate, nitrite and organic nitrogen
}

\author{
Carlo Nicoletto*, Ferdinando Pimpini \\ Department of Environmental Agronomy and Crop Science, Agripolis - University of Padova, \\ Viale dell'Università 16, 35020 Legnaro (PD), Italy
}

Received: 11 June 2009. Accepted: 28 October 2009.

\begin{abstract}
Radicchio "Rosso di Treviso tardivo" (Cichorium intybus L., group rubifolium), a typical vegetable of north-eastern Italy, has gained increasing commercial interest in recent years due to its particular shape and culinary features. These properties are obtained by a forcing process that could affect nitrate and dangerous nitrite contents in the edible product. The experiment was conducted in Veneto (north-eastern Italy, $45^{\circ} 36^{\prime} \mathrm{N}$; $12^{\circ} 10^{\prime} \mathrm{E}$ ) with plants grown in a loamy soil and analyzed at harvest and during the forcing process (0-10 and 20 forcing days-FD). Results showed that nitrate and nitrite contents in edible portions never exceed the most restrictive EU limits. A continuous reduction in $\mathrm{NO}_{3}$ content was observed during the forcing process, while $\mathrm{NO}_{2}$ showed a peak at 10 FD. Organic $\mathrm{N}$ significantly increased during the forcing process due to $\mathrm{NO}_{2}$ reduction. From a nutritional point of view these results further demonstrate that this type of radicchio is a healthy vegetable for the consumers.
\end{abstract}

Key-words: chicory, forcing times, plant parts, leaf portions, nitrogen, quality.

\section{Introduction}

Radicchio "Rosso di Treviso tardivo" (Cichorium intybus L., group rubifolium) is a typical chicory of the Veneto Region (north-eastern Italy). In recent years this chicory has been gaining increasing commercial interest due to its particular shape and culinary features. These properties are obtained by a post-harvest forcing process carried out in a dark room at a temperature of $10-15{ }^{\circ} \mathrm{C}$ for $15-20$ days. These conditions are fundamental to improve the product's aesthetic and nutritional quality and to increase the market value. Besides the aesthetic and morphological aspects, nutritional and healthy characteristics in high-quality food are increasingly requested by consumers, but the vegetable industry is not always able to satisfy this demand because of little or no knowledge about some species. Radicchio and all its cultivars are among these little-known vegetables.

Nitrate $\left(\mathrm{NO}_{3}\right)$ and nitrite $\left(\mathrm{NO}_{2}\right)$ contents are the factors most often evaluated in leafy vegetables. $\mathrm{NO}_{3}$ is absorbed by plants in the soil and used for protein formation (Trinchera, 2001). It can be a serious threat to human health (Santamaria et al., 2002; Santamaria, 2006), although recent researches have shown that nitrate also has beneficial effects (McKnight et al., 1997; Lundberg et al., 2006). Nitrate per se is relatively non-toxic (Speijers, 1996), but approximately $5 \%$ of all ingested $\mathrm{NO}_{3}$ is converted in the saliva and gastrointestinal tract into the more toxic nitrite (Spielgelhalder et al., 1976; Pannala et al., 2003) by bacterial enzymes (Mesinga et al., 2003). Nitrite and N-nitroso 
compounds, which form when nitrite binds to other substances before or after ingestion (for example, the amines derived from proteins), are toxic and can lead to severe pathologies in humans (Speijers and Van den Brant, 2003). The best-known effect of nitrite is its ability to react with hemoglobin (oxyHb) to form methemoglobin (metHb) and nitrate:

$$
\mathrm{NO}_{2}^{-}+\operatorname{oxyHb}\left(\mathrm{Fe}^{2+}\right) \rightarrow \operatorname{metHb}\left(\mathrm{Fe}^{3+}\right)+\mathrm{NO}_{3}^{-}
$$

Oxygen delivery to tissues is impaired as a consequence of the formation of metHb (Speijers and Van den Brant, 2003). Once the proportion of metHb reaches $10 \%$ of normal $\mathrm{Hb}$ levels, clinical symptoms (from cyanosis through to asphyxia) occur. This potentially fatal condition is known as methemoglobinaemia and babies less than three months old are particularly susceptible (Knobeloch et al., 2000; McKnight et al., 1997). Nitrate and nitrite can also determine metabolism problems (Hartman, 1983), carcinogenity (Broitman et al., 1981; Hathcock, 1982; Fraser, 1985) and mutagenicity (Luca et al., 1987; Inui et al., 1979). To avoid these problems, in the last report on toxicological evaluation of nitrate and nitrite the World Health Organization (WHO) have set an Acceptable Daily Intake (ADI) of $0.65 \mathrm{mg} \mathrm{kg}^{-1}$ bodyweight (bw) for $\mathrm{NO}_{3}$ and of $0.06 \mathrm{mg} \mathrm{kg}^{-1}$ bw for $\mathrm{NO}_{2}$ (Santamaria, 2006). Given that vegetables constitute the major dietary source of nitrate (Santamaria, 1997), it is obviously useful to evaluate its content together with nitrite in radicchio. Our research objective was to evaluate nitrate, nitrite and organic nitrogen content changes from harvest time to commercial product after the forcing process on "Rosso di Treviso tardivo".

\section{Materials and methods}

\section{Cropping conditions and plant material}

The experiment was conducted in 2007-2008 at Zero Branco (Treviso province, north-eastern Italy, $45^{\circ} 36^{\prime} \mathrm{N} ; 12^{\circ} 10^{\prime} \mathrm{E}$ ) on a loamy soil (sand $36 \%$, silt $38 \%$ and clay $26 \%$ ). The main crop management practices and dates are reported in Table 1 . Three plots $25 \mathrm{~m}^{2}(5 \times 5 \mathrm{~m})$ were singled out and 35 representative plants were uprooted from each of these at harvest time. After harvest and before starting the forcing process ( 0 forcing days $-0 \mathrm{FD})$, the qualitative characteristics were evaluated on a sample of 5 plants. The remaining plants, with their taproot cut at $0.20-0.25 \mathrm{~m}$, were gathered together in two bundles (15 plants each) and placed in a tank in a dark room for the forcing process. Well water at $11-13{ }^{\circ} \mathrm{C}$ was fed continuously into the tank from one side and, after reaching the level of the plant stem bases, flowed out from the opposite side. This technique maintained the required temperature at root level. Qualitative analyses were performed on 5 plants midway (10 FD) and at the end of the forcing process $(20 \mathrm{FD})$. This gave a total of 3 sampling times (0,10 and $20 \mathrm{FD})$.

Each plant was divided into five parts as follows: leaves were removed from stem, washed and dried, then separated into outer, intermediate and inner leaves (head), stem and roots were also considered. The leaves were cut in half along the midrib in order to have two mirror parts to use: a) to create a whole leaf sample; b) to separate veins from leaf blade. Similar parts from each plant were put together and mixed to give a homogeneous sample. A total of 11 plant parts were obtained: outer (1), in-

Table 1. Crop management practices during the experiment.

\begin{tabular}{lcc}
\hline Crop management practices & Dates & Notes \\
\hline Fertilization & $3 / 7 / 07$ & $0.13 .26+3 \mathrm{Mg}+0.2 \mathrm{~B}\left(500 \mathrm{~kg} \mathrm{ha}^{-1}\right)$ \\
Seed origin & & self-produced \\
Field sowing & $6 / 7 / 07$ & \\
Emergence & $16 / 7 / 07$ & \\
Irrigations & $8-10-12-14-16 / 7 / 07$ & volume $100 \mathrm{~m}^{3} \mathrm{ha}^{-1}$ \\
Irrigation method & & sprinkling \\
Thinning & $10 / 8 / 07$ & inter row tillage \\
Cultivation & $30 / 8 / 07$ & uprooting \\
Harvest & $20 / 11 / 07$ & 25 \\
Plot area $\left(\mathrm{m}^{2}\right)$ & & $0.45 \mathrm{x} 0.30$ \\
Distance between plants $(\mathrm{m})$ & & 7.4 \\
Plant density (plants $\left.\mathrm{m}^{-2}\right)$ & & \\
\hline
\end{tabular}


termediate (2) and inner (3) leaves, stem (4) and roots (5), outer (6), intermediate (7) and inner (8) leaf blades, outer (9), intermediate (10) and inner (11) veins.

\section{Dry matter}

Samples dry matter was obtained in a PID System ventilated oven (model M80-VF; Instruments s.r.l.; Bernareggio (MI), Italy) set at 65 ${ }^{\circ} \mathrm{C}$ for 72 hours.

\section{Compositional analysis}

Nitrate content was determined colorimetrically as described by Cataldo et al. (1975). Approximately $0.2 \mathrm{~g}$ chicory dry matter was boiled for 30 minutes and then filtered through 589 Schleicher filter paper. The extract was used after cooling. The standard curve was developed with $\mathrm{KNO}_{3}$.

Nitrite content was evaluated using an adaptation of the method proposed by Strickland and Parsons (1968) using the same extract as that for $\mathrm{NO}_{3}$. In the method, nitrite is allowed to react with sulfanilamide in an acid solution $\left(10 \mathrm{~g} \mathrm{~L}^{-1}\right.$ in $\left.\mathrm{HCl} 3 \mathrm{~N}\right)$. The resulting compound reacts with $\mathrm{N}$-(1-naphtyl)-ethylene diamine dihydrochloride $\left(0.2 \mathrm{~g} \mathrm{~L}^{-1}\right.$ in $\left.\mathrm{H}_{2} \mathrm{O}\right)$ to form a pink solution, whose absorbance is measured at 540 $\mathrm{nm}$ (Shimadzu UV-1800). The standard curve was developed with $\mathrm{KNO}_{2} 0.002 \mathrm{M}$.

The nitrogen content was measured by the Kjeldhal method (ISO1656).

All reagents were of analytical grade.

\section{Statistical analysis}

Statistical analysis (ANOVA) was performed considering the five main plant parts from (1)

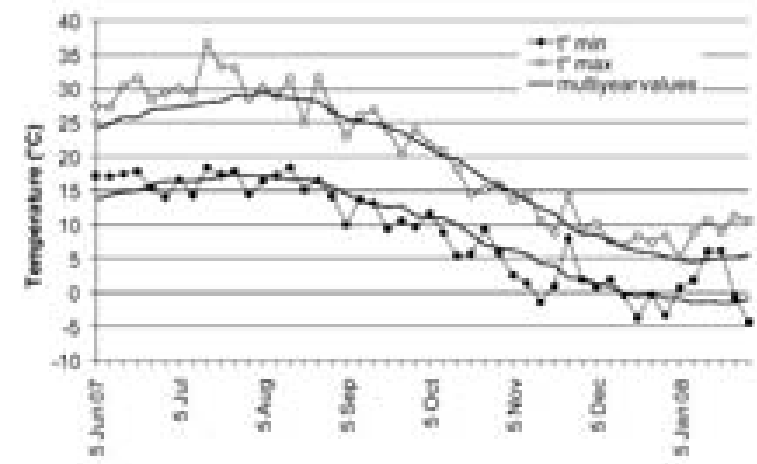

Figure 1. Five-day averages of maximum and minimum temperatures $\left({ }^{\circ} \mathrm{C}\right)$ recorded during the experiment and multiyear values (1992-2007). to (5), which were factorially combined with 3 forcing periods $(0,10$ and $20 \mathrm{FD})$ to obtain 15 theses. When we refer to the whole plant, values were obtained from the weighted average of 5 fractions.

Two leaf parts values (leaf blade and vein) were factorially combined with 3 leaf positions (outer, intermediate and inner) and with 3 forcing periods $(0,10$ and $20 \mathrm{FD})$ to obtain 18 theses. Because of whole leaf dependence these data were elaborated separately.

Averages were separated with Tukey's HSD test.

\section{Meteorological data}

Temperature, relative humidity $(\mathrm{RH})$ and rainfall data during the experiment period and multiyear data (1992-2007) were collected at the ARPAV (Veneto-Territory Safety Department) meteorological station in Zero Branco (Fig. 1). The values of max temperature recorded during the experiment were very different from the multiyear data in June and July, being even more than $10{ }^{\circ} \mathrm{C}$ higher during the first half of July. Afterwards there were no relevant variations until the first half of December; after this period $\mathrm{t}^{\circ}$ max was always higher than the multiyear data. Min $t^{\circ}$, after an initial variation in the first 20 days of June, stayed around the multiyear values till $25^{\text {th }}$ August. Then from $25^{\text {th }} \mathrm{Au}-$ gust to $5^{\text {th }}$ January 2008, except for the period from $5^{\text {th }}$ to $10^{\text {th }}$ September, on the $5^{\text {th }}$ and $25^{\text {th }}$ October, $25^{\text {th }}$ November and $10^{\text {th }}$ December, values were always lower than the multiyear data. In the last period of the crop cycle, similarly to $\max \mathrm{t}^{\circ}$, increasing temperatures were recorded till $25^{\text {th }}$ January 2008. Rainfall data (Fig. 2) showed that the total rainfall during the exper-

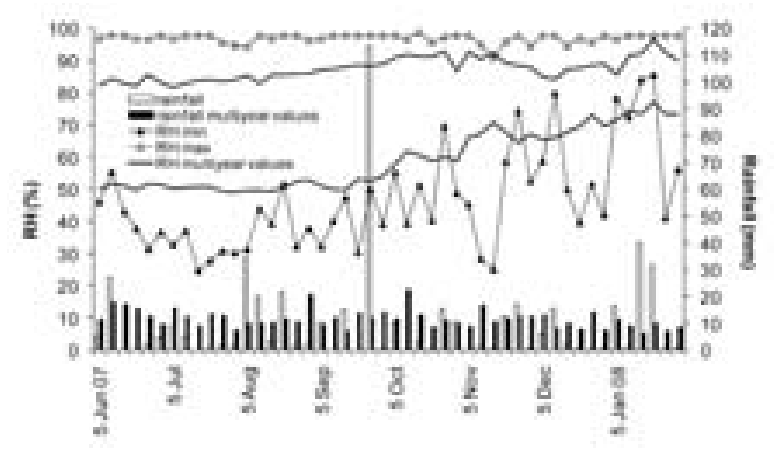

Figure 2. Five-day averages of maximum and minimum relative humidity and five-day cumulative rainfall recorded during the experiment and multiyear values (1992-2007). 
imental period was $465.8 \mathrm{~mm}, 16.7 \%$ lower than the multiyear values $(559.0 \mathrm{~mm})$. There were particularly heavy rainfall events during the first 20 days of August. The amount and rainfall distribution obviously influenced RH trend (Fig. 2). RH max values recorded during the experiment, except for $15^{\text {th }}$ November, were always higher than the multiyear data. RH min was always lower than the expected values, except for $10^{\text {th }}$ June, 20 ${ }^{\text {th }}$ August, 25 ${ }^{\text {th }}$ November, $5^{\text {th }}$ December and early January.

\section{Results}

\section{Weight variations}

During the forcing process (Fig. 3), only outer leaves showed a relevant weight reduction of $89.0 \%$. Other plant parts instead displayed a general increase of this parameter although with different intensity. In fact, after the forcing process, inner leaves (head) exhibited the highest weight increase of $70.0 \%$. Stem, similarly to other plant parts, had a lower weight gain $(60.3 \%)$ than the head; roots and intermediate leaves, after an initial and slight weight reduction, increased their values over the next $10 \mathrm{FD}$ by $17.8 \%$ and $73.3 \%$ respectively.

\section{Dry matter}

During the forcing process a general dry matter percentage decrease of the whole plant was observed (Tab. 2). Values varied from $14 \%$ at

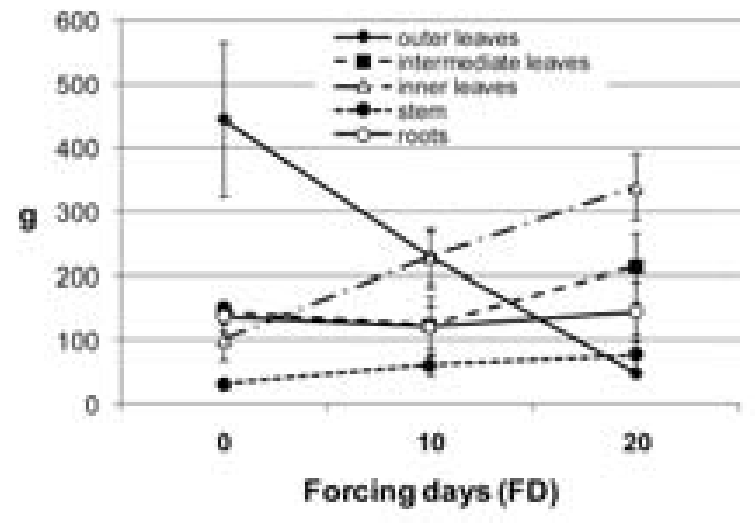

Figure 3. Different influence of forcing days (FD) on plant parts fresh weight $(\mathrm{g})$.

Interaction is significant at $\mathrm{P} \leq 0.01$. Vertical bars indicate standard error.

harvest ( 0 forcing days $-\mathrm{FD}$ ) to $8.2 \%$ at $20 \mathrm{FD}$. Roots had the highest dry matter percentage $(21.6 \%)$, followed by stem $(17.4 \%)$, outer and intermediate leaves (9.9 and $9.7 \%$ respectively) and inner ones $(8.5 \%)$.

Interesting dry matter content variations occurred in different plant parts during the forcing process ("interaction plant parts $\mathrm{x}$ forcing days"). The leaves (Fig. 4A) belonging to the head showed the higher dry matter percentage reduction from $11.8 \%$ ( $0 \mathrm{FD})$ to $6.0 \%(20 \mathrm{FD})$; for outer leaves, instead, the decrease was limited to $2.9 \%$. Roots and stem had gradual reductions of 5.5 and $8.4 \%$ respectively.

Table 2. Effects of plant parts and forcing days on some qualitative traits of radicchio during the forcing process.

\begin{tabular}{|c|c|c|c|c|}
\hline \multirow[t]{2}{*}{ Treatments } & \multicolumn{4}{|c|}{ Qualitative traits } \\
\hline & $\begin{array}{l}\text { Dry matter } \\
(\%)\end{array}$ & $\begin{array}{c}\text { Nitrate } \\
\left(\mathrm{mg} \mathrm{kg}^{-1} \text { d.w. }\right)\end{array}$ & $\begin{array}{c}\text { Nitrite } \\
\left(\mathrm{mg} \mathrm{kg}^{-1} \text { d.w. }\right)\end{array}$ & $\underset{(\%)}{\text { Organic } N}$ \\
\hline \multicolumn{5}{|l|}{ Plant parts } \\
\hline \multirow{3}{*}{$\begin{array}{ll}\text { Leaves } & \text { outer } \\
& \text { intermediate } \\
& \text { inner }\end{array}$} & $9.9 \mathrm{c}$ & $3383 \mathrm{c}$ & $1.67 \mathrm{c}$ & $1.4 \mathrm{c}$ \\
\hline & $9.7 \mathrm{c}$ & $3061 \mathrm{c}$ & $33.4 \mathrm{a}$ & $2.6 \mathrm{~b}$ \\
\hline & $8.5 \mathrm{~d}$ & $4006 \mathrm{c}$ & 30.9 a & $3.5 \mathrm{a}$ \\
\hline Stem & $17.4 \mathrm{~b}$ & 7912 b & $4.0 \mathrm{bc}$ & $2.7 \mathrm{~b}$ \\
\hline Roots & $21.6 \mathrm{a}$ & $15490 \mathrm{a}$ & $9.3 \mathrm{~b}$ & $2.2 \mathrm{~b}$ \\
\hline Average & 13.4 & 6770 & 15.9 & 2.5 \\
\hline Weighted average & 13.0 & 6530 & 15.0 & 2.3 \\
\hline \multicolumn{5}{|l|}{ Forcing days (FD) } \\
\hline 0 & $16.3 \mathrm{a}$ & 7047 a & $3.29 \mathrm{~b}$ & $2.3 \mathrm{a}$ \\
\hline 10 & $13.0 \mathrm{~b}$ & $6806 \mathrm{~b}$ & $39.5 \mathrm{a}$ & $2.5 \mathrm{ab}$ \\
\hline 20 & $10.9 \mathrm{c}$ & $6457 \mathrm{c}$ & $4.85 \mathrm{~b}$ & $2.7 \mathrm{~b}$ \\
\hline Average* & 13.4 & 6770 & 15.9 & 2.5 \\
\hline
\end{tabular}

* Average of three forcing times 0-10-20 FD.

Within plant parts and forcing days, column values with no letter in common differ significantly at $\mathrm{P} \leq 0.01$ (Tukey HSD test). 

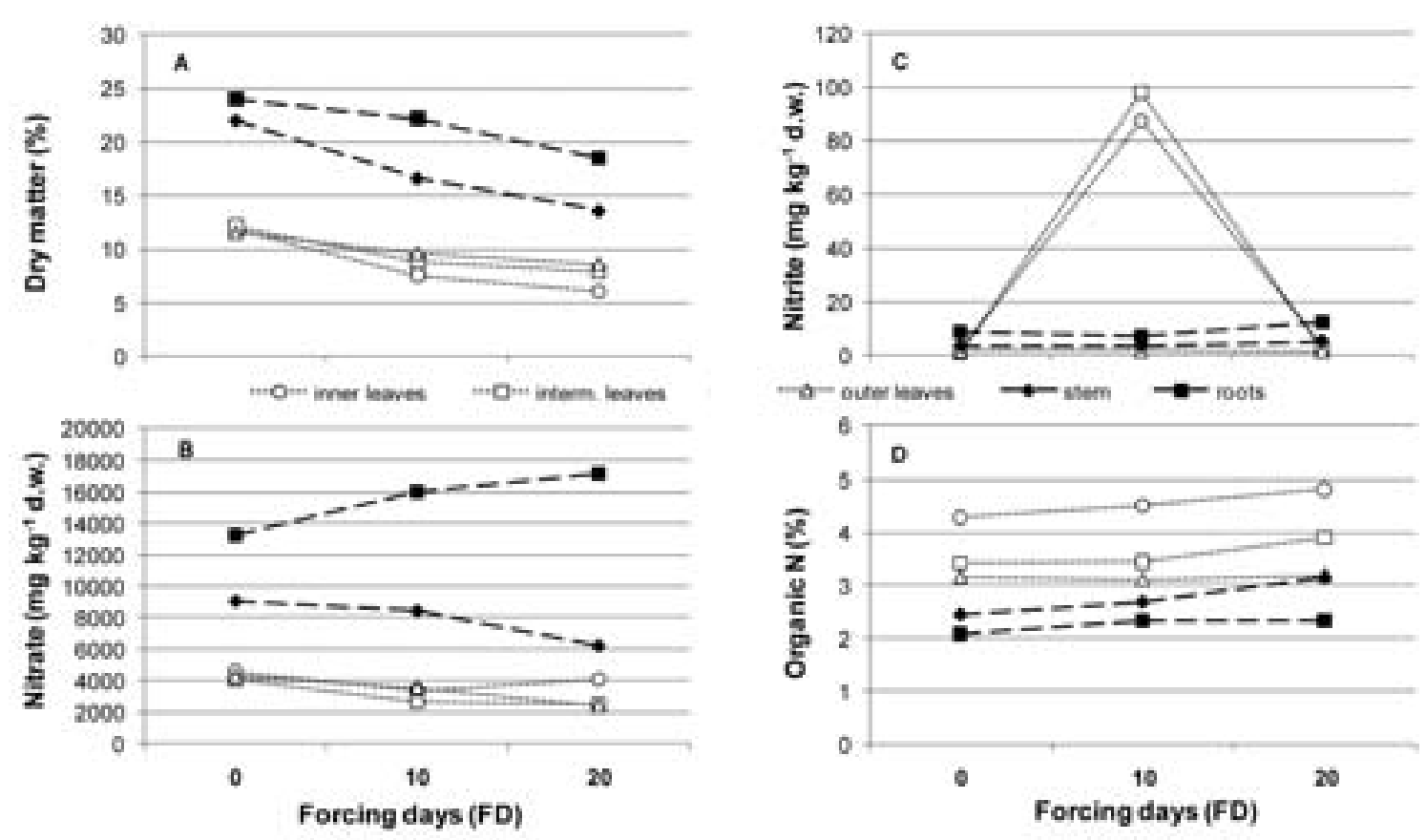

Figure 4. Different influence of forcing days on dry matter (A), nitrate (B), nitrite (C) and organic nitrogen (D) in plant parts. Interactions $\mathrm{A}, \mathrm{B}$ and $\mathrm{C}$ significant at $\mathrm{P} \leq 0.01 ; \mathrm{D}$ not significant.

Comparison of leaf blades and veins (Tab. 3) showed the higher concentration for the former and for all leaf positions, with an average increase of $49.0 \%$. The significance of the interaction "leaf parts $\mathrm{x}$ leaf position" is justified by the different intensity of responses. In this case a consistent decrease $(41.0 \%)$ from 0 to $20 \mathrm{FD}$ and from outer to inner leaves $(8.3 \%)$ was observed. Also in this case the interaction "forcing days $\mathrm{x}$ leaf position" was due to the different intensity of response. For all leaf blades (Fig. 5A) there was a considerable decrease in dry matter, from $18.0 \%$ to $10.0 \%$, between 0 and 10 FD; from 10 to 20 FD only outer and inner leaf blades showed a further dry matter reduction of 1.9 and $0.4 \%$ respectively. There were small reductions during the forcing process for outer and intermediate veins, while relevant differences were shown by inner leaf veins $(4.2 \%)$.

\section{Nitrate}

During the forcing process the $\mathrm{NO}_{3}$ content of the whole plant decreased from $7047 \mathrm{mg} \mathrm{kg}^{-1}$ dry weight (d.w.) (1342 $\mathrm{mg} \mathrm{kg}^{-1}$ fresh weight (f.w.)) at harvest (Tab. 2), to $6457 \mathrm{mg} \mathrm{kg}^{-1}$ d.w. (943 $\mathrm{mg} \mathrm{kg}^{-1}$ f.w.) at $20 \mathrm{FD}$, i.e., by $8.3 \%$ on d.w. and $29.7 \%$ on f.w.. The main effect of plant parts highlighted that higher $\mathrm{NO}_{3}$ concentration was found in roots $\left(15490 \mathrm{mg} \mathrm{kg}^{-1}\right.$ d.w.). This was $48.9 \%$ higher than stem content. Considering the whole leaves, values did not statistically differ among leaf positions, being from $3061 \mathrm{mg}$ $\mathrm{kg}^{-1}$ d.w. in the intermediate leaves to $4006 \mathrm{mg}$ $\mathrm{kg}^{-1}$ d.w. in the inner ones. Plant parts showed different trends of $\mathrm{NO}_{3}$ contents (interaction "plant parts $\mathrm{x}$ forcing days"). The whole leaves had a general reduction in values during first 10 FD (Fig. 4B) that, except for inner leaves, continued till the end of the forcing process. A continually decreasing content was observed in stem, while roots were the only plant part with a $23 \% \mathrm{NO}_{3}$ increase. Concerning leaf parts, veins always showed higher $\mathrm{NO}_{3}$ values (Tab. 3) although with different intensity. The average increase compared to leaf blades was $58.3 \%$. For the main effect of forcing days and leaf positions, in the former case a contraction in values from 0 to $20 \mathrm{FD}$ was observed; in the latter intermediate leaves displayed the higher $\mathrm{NO}_{3}$ content at just above $3200 \mathrm{mg} \mathrm{kg}^{-1}$ d.w. In relation to effects of leaf position and forcing periods, intermediate and inner leaves $\mathrm{NO}_{3}$ content decreased from 0 to $20 \mathrm{FD}$, while a higher con- 
centration for outer ones was observed at $10 \mathrm{FD}$. For leaf blades (Fig. 5B), higher $\mathrm{NO}_{3}$ content was observed in those intermediate at $0 \mathrm{FD}(4745 \mathrm{mg}$ $\mathrm{kg}^{-1}$ d.w.). Their content then considerably decreased, reaching $500 \mathrm{mg} \mathrm{kg}^{-1}$ d.w. at 20 FD. In outer leaf blades, $\mathrm{NO}_{3}$ content registered a slight increase of $10 \%$ at $10 \mathrm{FD}$, with a quick decrease at the end of the forcing process. Nitrate content in head leaf blades showed an $8.5 \%$ reduction from 0 to $20 \mathrm{FD}$. A general $\mathrm{NO}_{3}$ content decrease was also observed for leaf veins. Nitrate reduction in the inner veins was gradual throughout the forcing process; instead, for the intermediate ones, there was a drop from 4685 to $3090 \mathrm{mg} \mathrm{kg}^{-1}$ d.w. at $10 \mathrm{FD}$, followed by a slight increase to $3647 \mathrm{mg}$ $\mathrm{kg}^{-1}$ d.w. at $20 \mathrm{FD}$. The $\mathrm{NO}_{3}$ trend for outer leaf veins was interesting, which, contrary to the intermediate ones, showed a slight increase from 4124 to $4336 \mathrm{mg} \mathrm{kg}^{-1} \mathrm{~d}$.w. during the first $10 \mathrm{FD}$. A slight reduction, about $22.0 \%$, followed at $20 \mathrm{FD}$.

\section{Nitrite}

Nitrite $\left(\mathrm{NO}_{2}\right)$ content increased by $91.7 \%$ from 0 to $10 \mathrm{FD}$, to then fall $87.7 \%$ by $20 \mathrm{FD}$, leaving a content of $4.8 \mathrm{mg} \mathrm{kg}^{-1}$ d.w (Tab. 2).
Higher $\mathrm{NO}_{2}$ concentration was observed in intermediate and inner leaves, followed by roots. Stem and outer leaves showed values lower than $4.0 \mathrm{mg} \mathrm{kg}^{-1}$ d.w.. Nitrite also showed different responses during the forcing process (interaction "plant parts $\mathrm{x}$ forcing days"). Values were always close to 0 in the outer leaves (Fig. 4C). Instead, the intermediate and inner leaves presented very low values at $0 \mathrm{FD}$, which increased to reach values over $85 \mathrm{mg} \mathrm{kg}^{-1}$ d.w. at $10 \mathrm{FD}$, then drastically decreased at 20 FD. Roots showed a slight decrease of $\mathrm{NO}_{2}$ content during the first $10 \mathrm{FD}$, then increased to 12.2 mg kg-1 d.w. at 20 FD. $\mathrm{NO}_{2}$ expressed a different trend in the stem, where an increase from 3.5 (0 FD) to 5.2 (20 FD) $\mathrm{mg} \mathrm{kg}^{-1}$ d.w. was observed.

Regarding leaf parts (Tab. 3), leaf blades differed significantly from veins, with values $59.0 \%$ higher. Concerning leaf position effect, higher contents were observed for intermediate and inner leaf blades, while for the outer ones higher values were found in their veins. The main effect of forcing days showed higher concentrations at $10 \mathrm{FD}$ and that of leaf position dis-

Table 3. Effects of forcing days, leaf position and leaf parts on some qualitative traits of radicchio.

\begin{tabular}{|c|c|c|c|c|c|c|}
\hline \multirow[t]{2}{*}{ Leaf position } & \multicolumn{3}{|c|}{ Forcing days (FD) } & \multicolumn{2}{|c|}{ Leaf parts } & \multirow[t]{2}{*}{ Average } \\
\hline & 0 & 10 & 20 & blades & $\overline{\text { veins }}$ & \\
\hline \multicolumn{7}{|c|}{ Dry matter (\%) } \\
\hline Outer & 14.0 & 9.8 & 8.5 & 12.3 & 9.2 & $10.8 a$ \\
\hline Intermediate & 13.9 & 9.3 & 8.8 & 12.7 & 8.6 & $10.7 a$ \\
\hline Inner & 13.8 & 8.4 & 7.5 & 12.4 & 7.4 & $9.9 b$ \\
\hline Average & $13.9 \mathrm{a}$ & $9.2 \mathrm{~b}$ & $8.2 \mathrm{c}$ & $12.5 \mathrm{~A}$ & $8.4 \mathrm{~B}$ & \\
\hline \multicolumn{7}{|c|}{ Nitrate (mg kg-1 d.w.) } \\
\hline Outer & 2818 & 3107 & 1731 & 1217 & 3887 & $2552 b$ \\
\hline Intermediate & 4715 & 3104 & 2074 & 2788 & 3807 & $3298 a$ \\
\hline Inner & 3106 & 2783 & 2399 & 1063 & 4462 & $2762 b$ \\
\hline Average & 3546 a & 2998 b & $2068 \mathrm{c}$ & $1690 \mathrm{~B}$ & $4052 \mathrm{~A}$ & \\
\hline \multicolumn{7}{|c|}{ Nitrite (mg kg-1 d.w.) } \\
\hline Outer & 6.98 & 2.88 & 2.46 & 1.74 & 6.47 & $4.11 c$ \\
\hline Intermediate & 1.29 & 23.94 & 2.62 & 16.23 & 2.33 & $9.28 b$ \\
\hline Inner & 0.74 & 26.31 & 6.96 & 17.12 & 5.55 & $11.34 a$ \\
\hline Average & $3.00 \mathrm{~b}$ & $17.71 \mathrm{a}$ & $4.01 \mathrm{~b}$ & $11.70 \mathrm{~A}$ & $4.79 \mathrm{~B}$ & \\
\hline \multicolumn{7}{|c|}{ Organic N (\%) } \\
\hline Outer & 2.0 & 1.9 & 1.9 & 2.7 & 1.2 & $1.9 \mathrm{~b}$ \\
\hline Intermediate & 2.8 & 3.2 & 3.5 & 4.3 & 2.1 & $3.2 a$ \\
\hline Inner & 3.1 & 3.5 & 3.7 & 3.9 & 3.0 & $3.5 a$ \\
\hline Average & $2.6 \mathrm{~b}$ & $2.9 \mathrm{ab}$ & $3.0 \mathrm{a}$ & $3.6 \mathrm{~A}$ & $2.1 \mathrm{~B}$ & \\
\hline
\end{tabular}

Within forcing days (lower-case letters), leaf position (letters in italics) and leaf parts (capital letters), values with no letter in common differ significantly at $\mathrm{P} \leq 0.01$ (Tukey HSD test). 

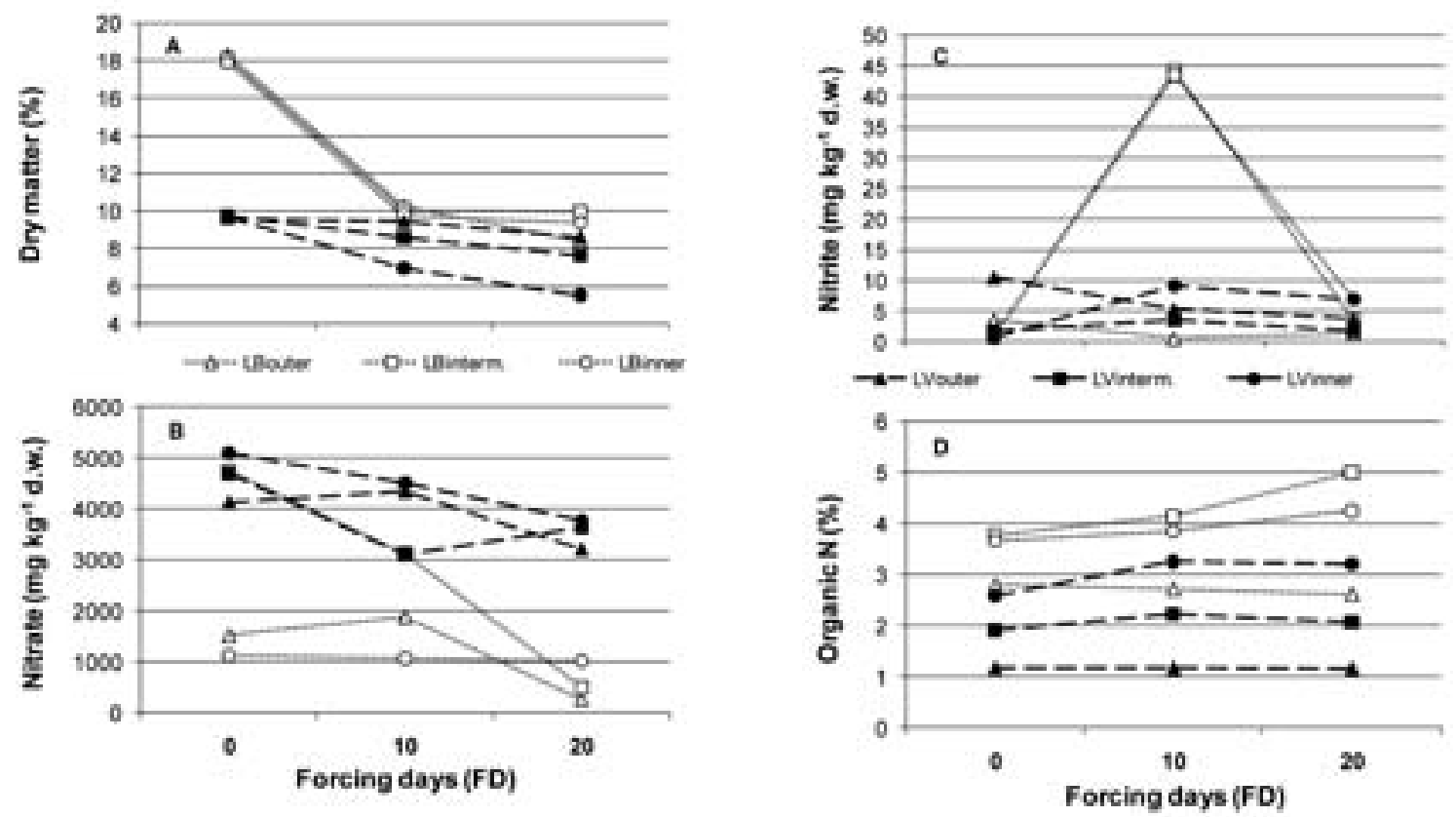

Figure 5. Different influence of forcing days on dry matter (A), nitrate (B), nitrite (C) and organic nitrogen (D) in two leaf parts (leaf blades-LB, leaf veins-LV) at three positions (outer, intermediate and inner).

Interactions $\mathrm{A}, \mathrm{B}$ and $\mathrm{C}$ significant at $\mathrm{P} \leq 0.01$; $\mathrm{D}$ not significant.

played increasing values moving from outer to inner leaves. As reported in table 3, these two variables significantly interacted. The trend of whole leaves was followed by the respective blades (Fig. 5C). In particular, outer leaf blades always exhibited very low values, even less than $1 \mathrm{mg} \mathrm{kg}{ }^{-1}$ d.w. at $20 \mathrm{FD}$. Also in this case, intermediate and head leaf blades displayed a $98.0 \%$ increase in $\mathrm{NO}_{2}$ content between 0 FD and $10 \mathrm{FD}$, to then return almost to zero at 20 FD. Leaf veins always showed very low $\mathrm{NO}_{2}$ values. An increase from $0.60 \mathrm{mg} \mathrm{kg}^{-1} \mathrm{~d} . \mathrm{w}$ at harvest to $9.0 \mathrm{mg} \mathrm{kg}^{-1}$ d.w. at $10 \mathrm{FD}$ was observed for inner veins, which decreased to $7.0 \mathrm{mg} \mathrm{kg}^{-1}$ d.w. at $20 \mathrm{FD}$. Intermediate leaf veins had very low values, with a slight increase at $10 \mathrm{FD}$. A $65.0 \%$ continuous reduction was observed only for outer leaf veins.

\section{Organic nitrogen}

During the forcing process an organic $\mathrm{N}$ content increase was observed in the whole plant (Tab. 2). It increased from $2.3 \%$ at $0 \mathrm{FD}$ to $2.7 \%$ at 20 FD. In the different plant parts, inner leaves presented the highest concentration $(3.5 \%)$, followed by intermediate, stem and roots. The lowest values were observed in out- er leaves. Figure 4D shows that all plant parts displayed an increase in organic $\mathrm{N}$ of between 2 and $5 \%$ during the forcing process. The main effect of leaf parts showed statistically higher values in leaf blades than veins. The interaction between these two was significant for the different intensity of the response compared to leaf position. As regards forcing days and leaf position main effect, an increase of organic $\mathrm{N}$ content was observed from 0 to $20 \mathrm{FD}$ and from outer to inner leaves. The interaction "forcing days x leaf position" was not significant. It was also observed that the leaf parts results did not differ statistically during the forcing process (Fig. 5D).

\section{Discussion and conclusions}

The weight evolution of plant parts during the forcing process highlighted the drastic decrease in outer leaves due to senescence processes during the treatment. However, the head weight increased; this was determined by new leaves formation and the growth of younger leaves already present at harvest. The intermediate leaves, less affected by senescence than the out- 
er ones, had a weight increase at the end of the forcing treatment due to their growth. Similar behavior was observed in the roots. In fact, after an early slight loss of weight caused by sugar contents allocated to new leaves formation, roots exhibited a slight weight increase thanks to new roots formation. Stem showed a continuous weight increase, probably attributable to its lengthening due to inner leaves growth.

At harvest time, radicchio did not show a high nitrate content as already described by Pimpini et al. (2000). Indeed, apart from roots and stem, this chicory did not exceed the most restrictive limits imposed by the EU for other leafy species (Santamaria, 2006) already at harvest. Roots and stem exceed these limits because are composed of highly vascular tissues. Therefore, they have a high nitrate content, as observed by Pimpini et al. $(1970 ; 1971 ; 1973)$ in cauliflower and by Santamaria et al. (1999) in many other vegetables. Moreover, a further decrease in nitrate content was observed during the forcing process. This was probably due to the lack of nutrient uptake by roots during the storage period in pools filled only with well water. This was also observed by Santamaria et al. (2001) on rocket salad (Diplotaxis tenuifolia and Eruca vesicaria subsp. sativa) cultivated in a floating system after replacing nutrient solution with only water. During the forcing process, roots were the only plant part that presented a continuous increase in nitrate content, probably due to its reallocation from senescing plant parts (Cassan et al., 2008).

Regarding nitrite content, the peak observed at $10 \mathrm{FD}$ in intermediate and inner leaves, was probably due to a nitrite reductase activity (NiR) reduction caused by lack of light, as described by Datta and Sharma (1999) in Zea mais. These Authors also reported that, in those light conditions, the nitrate reductase (NR) activity was highly decreased compared to NiR. The drastic $\mathrm{NO}_{2}$ decrease verified from 10 to 20 FD was justified on this basis. In fact some relevant aspects that involved the forcing environment and plant have to be considered, as the experiment was conducted under extremely low light intensity, with plants dipped in plain water.

Plants also suffered a serious loss of roots at harvest, especially for the absorbent component, and the short duration of the forcing treatment allows little regeneration. This prevents the ab- sorption of any $\mathrm{NO}_{3}$ present in water. There is therefore a lower nitrite production from NR, while $\mathrm{NiR}$ can reduce any $\mathrm{NO}_{2}$ already present. This hypothesis is further supported by what was verified for organic $\mathrm{N}$, which increased in plant parts where $\mathrm{NO}_{2}$ reduction was observed.

At the end of the forcing process both nitrate and nitrite contents were abundantly lower than EU limits. In fact eating $100 \mathrm{~g}$ of fresh product (forced inner leaves), a person would consume nitrate and nitrite contents of 24.7 and $0.021 \mathrm{mg}$ respectively. These values do not in any way threaten human health because they represent 9.6 and $0.5 \%$ of the daily acceptable intake for a person weighing $70 \mathrm{~kg}$ (Santamaria et al., 2006). We can conclude that radicchio "Rosso di Treviso tardivo" presents no contraindications regarding the aspects considered in this study and it is a healthy vegetable for the consumer.

\section{References}

Broitman S.A., Velez H., Vitale J.J. 1981. A possible role of iron deficiency in gastric cancer in Colombia. Adv. Exp. Med. Biol., 135:155.

Cassan L., Corbineau F., Limami A.M. 2008. Genetic variability of nitrogen accumulation during vegetative development and remobilization during the forcing process in witloof chicory tuberized root (Cichorium intybus L.). J Plant Physiol., 165:1667-1677.

Cataldo D.A., Haroon M., Schrader L.E., Youngs V.L. 1975. Rapid colorimetric determination of nitrate in plant tissue by nitration of salicylic acid. Commun. Soil Sci. Plant. Anal., 6:71-80.

Datta R., Sharma R. 1999. Temporal and spatial regulation of nitrate reductase and nitrite reductase in greening maize leaves. Plant Science, 144:77-83.

Fraser P. 1985. Nitrates: epidemiological evidence. IARC Sci. Publ., 65:183.

Hartman P.E. 1983. Review: putative mutagens and carcinogens in foods. 1. Nitrate/nitrite ingestion and gastric cancer mortality. Environ. Mutagen., 5:111.

Hathcock J.N. 1982. Nutritional toxicology. Vol. 1. Academic Press, New York, NY.

Inui N., Nishi Y., Taketomi M., Mori M. 1979. Transplacental action of sodium nitrite on embryonic cells of Syrian golden hamster. Mutat. Res., 66:149.

Knobeloch L., Salna B., Hogan A., Postle J., Anderson H. 2000. Blue babies and nitrate-contaminated well water. Environ. Health Perspect, 108:675-678.

Luca D., Luca V., Cotor F., Rileanu L. 1987. In vivo and in vitro cytogenetic damage induced by sodium nitrite. Mutat. Res., 189:133. 
Lundberg J.O., Feelisch M., Björne H., Jansson E.A., Weitzberg E. 2006. Cardioprotective effects of vegetables: is nitrate the answer? Nitric Oxide, 15:359362.

McKnight G.M., Smith L.M., Drummond R.S., Duncan C.W., Golden M., Benjamin, N. 1997. Chemical synthesis of nitric oxide in the stomach from dietary nitrate in humans. Gut., 40:211-214.

Mesinga T.T., Speijers G.J.A., Meulenbelt J. 2003. Health implications of exposure to environmental nitrogenous compounds. Toxicol. Rev., 22:41-51.

Pannala A.S., Mani A.R., Spencer J.P.E., Skinner V., Bruckdorfer K.R., Moore K.P., Rice-Evans, C.A. 2003. The effect of dietary nitrate on salivary, plasma and urinary nitrate metabolism in humans. Free Rad. Biol. Med., 34:576-584.

Pimpini F., Filippini M.F., Sambo P., Gianquinto G. 2000. Influenza della concimazione sul contenuto di nitrato in due tipi di radicchio rosso. Riv. Agron., 34:406418.

Pimpini F., Venter F., Wünsch A. 1970. Untersuchungen über den Nitratgehalt in Blumenkohl. Landw. Forsch., 4:363-370.

Pimpini F., Venter F., Wünsch A. 1971. Über den Einfluß verschiedener Stickstoff-Formen und steigender Stickstoff-Meugen auf das Wachstum von Blumenkohl in Kulturgefaßen. Gartenbauweissenschaft, 36, 18:1-17.

Pimpini F., Venter F., Wünsch A. 1973. The influence of different nitrogen forms and increasing nitrogen doses on the content of total nitrogen and of nitrate in cauliflower plants. Acta Hort., 29:307-317.
Santamaria P. 1997. Contributo degli ortaggi all'assunzione giornaliera di nitrato, nitrito e nitrosammine. Industrie Alimentari, 36:1329-1334.

Santamaria P. 2006. Nitrate in vegetables: toxicity, content, intake and EC regulation. J. Sci. Food Agric., 86:10-17.

Santamaria P., Elia A., Serio F., Todaro, E. 1999. A survey of nitrate and oxalate content in fresh vegetables. J. Sci. Food Agric., 79:1882-1888.

Santamaria P., Gonnella M. 2001. Ways of reducing rocket salad nitrate content. Acta Hort., 548:529-536.

Santamaria P., Gonnella M., Valenzano V. 2002. Livelli di nitrato e commercializzazione degli ortaggi. Colture Protette, 12:7-13.

Speijers G.J.A. 1996. Nitrate. In Toxicological evaluation of certain food additives and contaminants in food. Food Additives Series, 35:325-360. World Health Organization, Geneva.

Speijers G.J.A., Van Den Brandt P.A. 2003. Nitrite and potential endogenous formation of $\mathrm{N}$-nitroso compounds. Food Additives Series, 50. World Health Organization, Geneva. http://www.inchem.org/documents/jecfa/jecmono/v50je05.htm [24 April 2009].

Spiegelhalder B., Eisenbrand G., Preussmann R. 1976. Influence of dietary nitrate on nitrite content of human saliva: possible relevance to in vivo formation of N-nitroso compounds. Food Cosmet. Toxicol., 14:545-548.

Strickland J.D.H., Parsons T.R. 1968. A manual for sea water analysis. Bull. Fish Res. Bd., 167, Canada.

Trinchera A., 2001. I nitrati nel metabolismo degli organismi viventi. Bollettino SISS, 50:875-884. 